\section{RSP}

http://www.rsp.fsp.usp.br/
Revista de Saúde Pública

\title{
Horizon scanning in Brazil: outputs and repercussions
}

\author{
Pollyanna Teresa Cirilo Gomes',1! (iD), Verónica Elizabeth Mata' iD, Thais Conceição Borges' \\ Dayani Galato" iD \\ ' Ministério da Saúde. Departamento de Gestão e Incorporação de Tecnologias em Saúde. Brasília, Distrito \\ Federal (DF), Brasil \\ " Universidade de Brasília. Faculdade de Ceilândia. Programa de Pós-Graduação em Ciências e Tecnologias da \\ Saúde. Distrito Federal (DF), Brasil
}

\section{ABSTRACT}

OBJECTIVE: To describe the four types of horizon scanning (HS) outputs developed by the National Committee for Health Technology Incorporation (CONITEC) and show their main repercussions on the decision-making processes of the Brazilian Ministry of Health (MH).

METHODS: Descriptive study based on participant observation and document analysis of HS outputs (internal reports, alert reports, briefs and sections for CONITEC recommendation reports) developed between January 2014 and July 2018.

RESULTS: Fifteen internal reports, six alert reports, two briefs and $57 \mathrm{HS}$ sections were produced. Each output has a specific structure according to its purpose. The methodological approach adopted for developing HS outputs in Brazil is described by EuroScan International Network. The outputs had institutional and international repercussions. The activities resulted in the inclusion of HS as a tool for reducing health lawsuits in the legal framework of the MH. One of the internal reports on a high-cost drug not approved in Brazil for a rare disease was requested by the Health Technology Assessments Network for the Americas (RedETSA), showing the international relevance of the outputs. The HS sections in recommendation reports influenced discussions about incorporating technologies into the Unified Health System.

CONCLUSIONS: The developed outputs have purposes ranging from helping build arguments for defense of the $\mathrm{MH}$ in cases of health judicialization to inform decision-making processes. In addition, HS sections in recommendation reports have grown in importance recently. CONITEC's HS system has been structured, and its role as a tool to inform health managers has shown to be been relevant.

DESCRIPTORS: Technology Assessment, Biomedical. Technology Control, Biomedical. Health Sciences, Technology, and Innovation Management. Policies and Cooperation in Science, Technology and Innovation. Evidence-Informed Policy.

How to cite: Gomes PTC, Mata VE, Borges TC, Galato D. Horizon scanning in Brazil: outputs and repercussions. Rev Saude Publica. 2019;53:111.

Copyright: This is an open-access article distributed under the terms of the Creative Commons Attribution License, which permits unrestricted use, distribution, and reproduction in any medium, provided that the original author

and source are credited.

Correspondence:

Esplanada dos Ministérios, Bloco G, CEP: 70058900

Brasília/DF, Brasil.

Received: 30 dez 2018

Approved: 27 jun 2019 


\section{INTRODUCTION}

In the last decades, the health field has been marked by the profusion of new technologies, not always safe, effective or with clinical superiority over those already available. Demand for health services and technologies has increased exponentially, with consequences for the allocation of human and financial resources, as well as the logistics for the implementation of health services ${ }^{1}$.

Facing the challenge of defining which technologies will be enabled by health systems, the use of health technology assessment (HTA) is increasing in support of decision-making processes $^{2}$. The incorporation, exclusion and alteration of technologies offered by the Unified Health System (SUS) are carried out with the advice of the National Committee for Health Technology Incorporation (CONITEC), with the application of the HTA ${ }^{3,4,5}$.

One of the HTA phases is horizon scanning (HS), which is the systematic identification of new and emerging technologies with the potential to impact health, health systems and/or society, with the purpose of timely informing decision-makers ${ }^{6}$. New technologies are those in the launching phase or in the early stages of diffusion of use in the health care system. Emerging technologies are in phases 2 or 3 of clinical research or in the pre-market phase ${ }^{7}$.

Several countries adopt HS as an approach to prepare their health systems for such technologies ${ }^{8-12}$. Discussions about the organization of a Brazilian HS system started more than 10 years ago through the Brazilian Health Technology Assessment Network (REBRATS) ${ }^{13,14}$.

Currently, the legal attribution of HS activities at federal level belongs to CONITEC ${ }^{3}$. CONITEC's HS system is part of the International Information Network on New and Emerging Health Technologies (EuroScan), the largest collaboration network on new and emerging technologies. SUS is the main client of CONITEC's system ${ }^{15,16}$.

In response to different information needs, CONITEC's HS system has developed internal reports, alert reports, briefs and HS sections in the committee's recommendation reports. The purpose of this study was to describe the main characteristics of these outputs and show the main repercussions generated by HS.

\section{METHODS}

Descriptive study, based on participant observation and documentary analysis of HS outputs prepared under CONITEC, between January 2014 and July 2018. Data collection was performed by searching the CONITEC website ${ }^{17}$. HS internal reports with restricted access were obtained from documentary research after formal authorization from the Ministry of Health (MH).

The publication "A toolkit for the identification and assessment of new and emerging health technologies"7 was used as a theoretical framework for the description of (i) internal reports, (ii) alert reports, (iii) briefs and (iv) HS sections in CONITEC recommendation reports. The resulting implications of HS outputs were shown by describing examples of the repercussions of the information in the $\mathrm{MH}$ and in the CONITEC plenary decisionmaking process.

\section{RESULTS}

The outputs were designed by applying the steps of the EuroScan toolkit? ${ }^{7}$. The technologies addressed in the outputs were indicated by the information requester (internal reports) or identified by searches in the clinical trial registry database ClinicalTrials.gov; on the websites of health regulatory agencies in Brazil (Brazilian Health Regulatory Agency ANVISA), Europe (European Medicines Agency - EMA) and the United States of America 
(Food and Drug Administration - FDA); in addition to EuroScan and Cortellis ${ }^{\text {"w }}$ databases. Table 1 shows the characterization of the outputs.

The recipients of output of the study period were MH managers, CONITEC plenary, and society. The outputs were prepared by an internal team of three people with 0.4 full-time equivalent HS workload (1.0 full-time equivalent corresponds to a weekly workload of 40-hours). Some of the outputs were designed by external partners of health technology assessment centers at two hospitals and one university, corresponding to 0.2 full-time equivalents. The outputs comprised four categories of health technologies, totaling 80 documents (Table 2).

Between 2015 and 2016, internal reports predominated $(n=13)$. Between 2016 and 2018, HS sections in CONITEC recommendation reports were the most frequent output (Figure 1).

Table 1. Characterization of the outputs developed by CONITEC's horizon scanning system during the analyzed period and the adopted steps, according to the EuroScan toolkit?

\begin{tabular}{lcccc}
\hline & Internal Reports & Alert reports & Briefs & $\begin{array}{r}\text { HS Sections in CONITEC } \\
\text { Recommendation Reports }\end{array}$ \\
\hline Target audience & MH managers & Society ${ }^{18}$ & $\begin{array}{c}\text { MH health professionals, } \\
\text { academy and managers }\end{array}$ & CONITEC plenary
\end{tabular}

Purpose
To respond the applicant's specific questions (answers to court demands)
To disseminate information on new and emerging technologies and warn against the possibility of improper diffusion of these technologies
To support CONITEC Plenary discussions and prepare health care system for new and emerging technologies

Digital (in recommendation reports) and oral (in CONITEC meetings)

Format

Printed

Digital
Medicines and medical devices

\section{Medicines, diagnostic}

methods, software

Technologies from phase 2 of clinical research; or without

Time horizon licensing with ANVISA, EMA or FDA; or newly approved by these agencies

Identification

Filtering and prioritization

of requesting information about a specific technology, filtering and prioritization were not performed

The information provided
depended on the applicant's
question. No predefined
template was established

$\begin{array}{lc}\text { Type of evaluation } & \text { Rapid, brief or in-depth } \\ \text { Dissemination } & \begin{array}{c}\text { Restricted circulation to the } \\ \text { information requester }\end{array}\end{array}$

Technologies from phase 3 of licensing with ANVISA, EMA or FDA; or newly registered at these agencies clinical research; or without

\section{Passive process}

Performed internally. Application of the criteria: $\mathrm{MH}$ spending on technology due to judicialization; burden of disease; availability of therapeutic options for the clinical condition in SUS. relevance of topic to $\mathrm{MH}$ policymakers

Predefined template ${ }^{18}$ with information on: analyzed technology, regulatory situation in Brazil and worldwide, clinical research data, existence of Brazilian

Clinical Guidelines published for the disease, scientific evidence of effectiveness and safety, technology impact predictions $^{18}$
Technologies from phase 2 of clinical research; or without licensing with ANVISA, EMA or FDA; or newly approved by these agencies
Performed internally. Application of the criteria: technologies from phase 2 of clinical research and without licensing for the therapeutic indication in ANVISA or recently registered in the country

No predefined template was established.

Information related to technology(ies), patient,

scientific evidence of efficacy and safety, and impact prediction on patient care and health services were addressed
Medicines

Technologies from phase 3 of clinical research; or without licensing with ANVISA, EMA or FDA; or newly registered at these agencies
Performed internally. Application of the criteria: technologies from phase 3 of clinical research and without licensing for the therapeutic indication in ANVISA or recently registered in the country

Predefined template with topics: active principle, mechanism of action, clinical trial status, regulatory data (designation or approval of use as an orphan drug and licensing by ANVISA, EMA and FDA). Efficacy and safety data were presented orally to the CONITEC plenary
In-depth

CONITEC website and mailing list; wide circulation
Rapid

\section{CONITEC Website}

Internal review, but subject to external review through public consultations to which reports are submitted 
Table 2. Number of horizon scanning outputs of the study period as to the health technology categories evaluated.

\begin{tabular}{lc}
\hline Type of output & Quantity per technology type addressed \\
\hline Internal report & (12) Medicine \\
& (2) Diagnostics \\
Alert report & (1) Software \\
Brief & (5) Medicine \\
HS section in recommendation reports & (1) Medical device \\
\hline
\end{tabular}

HS: horizon scanning

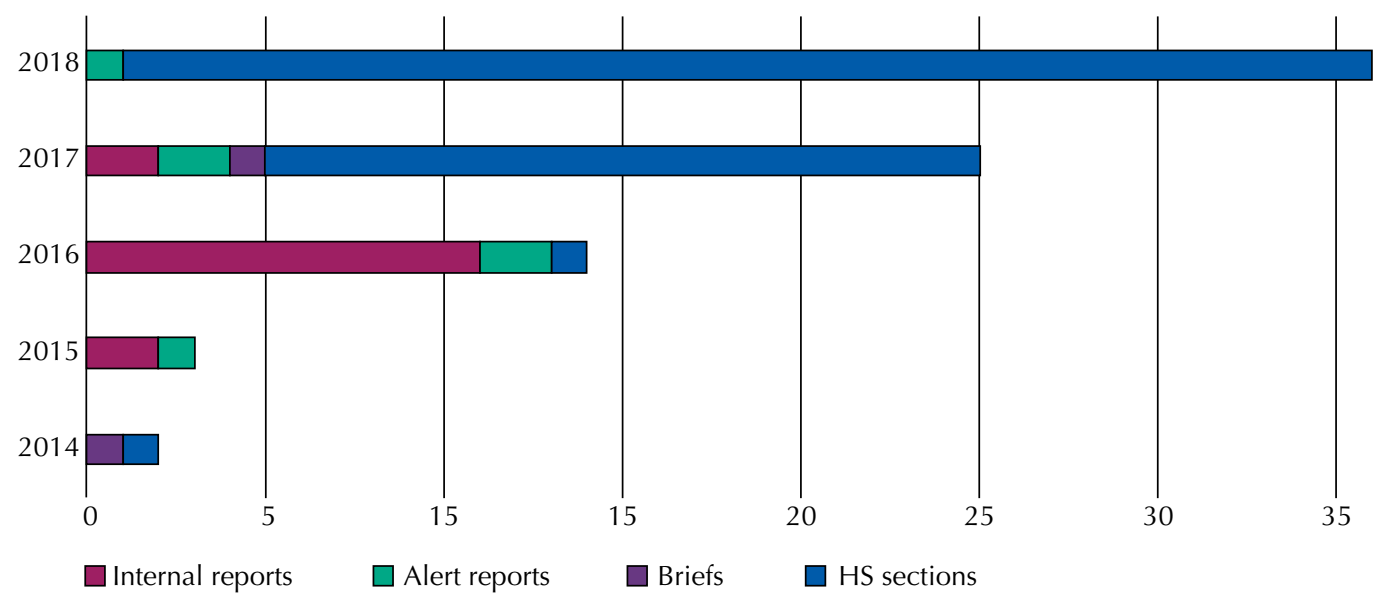

Figure 1. Number of technology horizon monitoring outputs prepared per year evaluated in the study.

The most frequent themes were related to rare diseases $(n=21)$, rheumatology $(n=10)$, neurology $(n=9)$, and oncology $(n=9)$. The other outputs were related to hematology, pneumology, cardiovascular system, infectology, endocrinology and others.

\section{Internal reports}

Internal reports aimed to support the defense of the MH in cases of drugs required by court; to assist in the definition of medicines to establish Partnerships for Productive Development (PDP); to provide information to patients, $\mathrm{MH}$ managers and policy makers; and support the development of Brazilian Clinical Guidelines (PCDT) ${ }^{19}$ (Table 3).

Two types of internal reports were produced, short and extensive ${ }^{16}$. The first ones, with four to six pages, covered a single technology. This approach, among the types of outputs developed by the HS system, was the most appropriate for delivering timely information on new and emerging medicines to managers, given the short time available for the preparation of MH judicial defenses (Table 3). Internal reports of the second type, the extensive ones, were in-depth reviews of one or several technologies for a given clinical indication, being the useful modality to support the development of clinical guidelines (Table 1).

Internal reports had restricted circulation. However, those related to familial amyloid polyneuropathy and homozygous familial hypercholesterolaemia were pertinent to other audiences. Thus, they were adapted to the brief and alert report formats, respectively.

One of the internal reports that exemplifies implications of HS activities in $\mathrm{MH}$ is the metreleptin report. In 2015, lawsuits were submitted to the $\mathrm{MH}$ requiring the drug for patients with Berardinelli-Seip syndrome, a rare disease consisting of congenital generalized lipodystrophy ${ }^{20}$. The drug, which has not been registered in Brazil, is a recombinant 
Table 3. Topics covered in internal horizon scanning reports and purposes.

\begin{tabular}{|c|c|}
\hline Topic & Purpose \\
\hline Beta idursulfase for mucopolysaccharidosis type 2 (Hunter syndrome) & \multirow{4}{*}{ Judicial defense } \\
\hline Mipomersen for homozygous familial hypercholesterolaemia & \\
\hline $\begin{array}{l}\text { Eculizumab for paroxysmal nocturnal hemoglobinuria and atypical } \\
\text { hemolytic uremic syndrome }\end{array}$ & \\
\hline Metreleptin for Berardinelli-Seip syndrome & \\
\hline Pompe disease & \multirow{4}{*}{ Elaboration of PCDT } \\
\hline Fabry's disease & \\
\hline Mucopolysaccharidoses type 1 and 2 & \\
\hline $\begin{array}{l}\text { Medicines for familial amyloidotic polyneuropathy associated with } \\
\text { transthyretin }\end{array}$ & \\
\hline Watson robot & \multirow{5}{*}{ To inform MH managers } \\
\hline Rapid diagnostic method of bacterial meningitis & \\
\hline Diagnostic method of colorectal cancer by stool DNA & \\
\hline Medicines for chronic hepatitis C & \\
\hline Severe asthma medications & \\
\hline Recombinant factors VIII for Haemophilia A & $\begin{array}{l}\text { Research and Development } \\
\text { (R\&D) }\end{array}$ \\
\hline Medicines for Amyotrophic Lateral Sclerosis & $\begin{array}{l}\text { Preparation for patients and } \mathrm{MH} \\
\text { managers meeting }\end{array}$ \\
\hline
\end{tabular}

PCDT: Brazilian clinical guidelines; MH: Ministry of Health

analogue of the human hormone leptin and had been approved by FDA in February 2014 for that clinical indication ${ }^{21}$. Each ampule of metreleptin costs about US\$ $1,766.40^{22}$, with an estimated spending of over $\$ 4$ million per year to treat patients. At that time, efficacy and safety data on the drug were scarce, and there was no HS study on the subject in the EuroScan database.

The HS internal report ${ }^{23}$ contained information on the disease, epidemiological data from Brazil and around the world, the description of the drug, the estimated costs of treatment with metreleptin, and evidence on efficacy and safety, as well as regulatory and clinical research situations for therapeutic indication. Despite the weak evidence in favor of the drug use to treat the disease, court decisions were favorable to its costing.

Subsequently, the HS report ${ }^{23}$ was shared with Argentina. The request for information was made through the Health Technology Assessments Network for the Americas (RedETSA). In Argentina, the drug was being requested for compassionate use of patients with the disease, which could result in high expenses, as in Brazil.

\section{Alert reports}

The purpose of alert reports was to predict the impact of new and emerging legally demanded technologies, as well as those that could be brought to court in the future. The recipients of the information were judges, patients, health professionals and managers, which was reflected on the use of simple language and brief extension. The alert reports included a technology for a therapeutic indication ${ }^{18}$.

Six alerts were produced in the period: ledispavir associated with sofosbuvir for chronic Hepatitis $\mathrm{C}$ genotype 1, eliglustate tartrate for type 1 Gaucher disease, mipomersen for homozygous familial hypercholesterolemia, ivacaftor for cystic fibrosis, medical device for severe mitral regurgitation in patients with high surgical risk, and aducanumab for Alzheimer's disease (Table 1). 
Briefs were intended to show potential new and emerging technologies for a health condition, addressing various technologies (Table 1). Two reports were produced during the study period: "Bioabsorbable stents in percutaneous coronary intervention" and "Drugs under development for treating familial amyloid polyneuropathy associated with transthyretin." These briefs covered two categories of technologies, medical devices and medicines (Figure 1), with the main target audience being health professionals and the academy.

\section{HS Sections in Recommendation Reports}

CONITEC's recommendation reports are official MH documents that include scientific evidence, economic evaluation, and budget impact assessment of health technologies submitted for analysis for incorporation into SUS 5 . HS sections had aimed to present the drugs that could potentially compete with the one being analyzed for incorporation into SUS, either by new route of administration or by representing a new therapeutic class, for example, to support the discussions of CONITEC 5 .

Pilot analyses of the technological landscape of drugs in clinical development for multiple sclerosis were performed during the evaluation of the demands of incorporation of fingolimod and teriflunomide in 2014 and 2016, respectively. The HS findings were shown to the CONITEC plenary, influencing the recommendation issued. Due to HS's role in decision-making, this output was systematically made for each drug under review by the commission ${ }^{24}$ as of 2017.

Between 2017 and July 2018, 58 HS sections were prepared, an average of three sections per month. The total of 153 new and emerging technologies were prospected. The most frequent health topics were rare diseases (23\%), oncology (19\%) and neurology (17\%). In addition to being included in the recommendation report, the information was presented orally to the plenary (Table 1) and impacted in discussions and decision-making processes.

One of these repercussions occurred in the context of the analysis to incorporate adalimumab, etanercept, infliximab, secukinumab and ustekinumab for moderate to severe psoriasis ${ }^{25}$. HS appointed 13 drugs for that clinical indication, and efficacy data for guselkumab, ixekizumab and brodalumab suggested superiority over adalimumab, etanecerpt, infliximab, and ustekinumab.

In addition, three emerging drugs (pliclidenoson, tofacitinib and voclosporin) were being developed for oral administration. On the other hand, all drugs under analysis for incorporation were administered subcutaneously or intravenously, indicating a potential positive repercussion of these technologies on patients' therapeutic compliance, if they were registered in the country.

The scenario of potentially more effective drugs with more convenience for the patient in the near future resulted in the intensification of the CONITEC plenary debate on the preliminary recommendation not to incorporate three of the drugs under consideration.

In 2017, institutional recognition of the key role of CONITEC's HS system in providing strategic information on new and emerging technologies to the $\mathrm{MH}$ resulted in the legal inclusion of horizon scanning as an activity of the commission's advisory department as a tool to reduce health lawsuits ${ }^{26}$.

\section{DISCUSSION}

This study describes HS outputs developed by the Brazilian MH in order to support the health technologies assessment in the context of one of the largest health systems in the world. The results show that the EuroScan toolkit ${ }^{7}$ has been applicable to the Brazilian HS system. The increase in the number of outputs produced per year shows that, over time, the potential of HS as a tool for collecting, synthesizing and presenting information 
on new and emerging technologies has been adopted in the decision-making processes in $\mathrm{MH}$.

We found that, although within the same HS system, the HS steps were not uniquely employed to build different outputs to provide information for specific audiences. The study points out a differential among Brazilian HS outputs: their close relation with the judicialization of health, in which technologies are required through the judiciary. This access mechanism has been a gateway for high cost drugs with great potential for inadequate diffusion and irrational use, especially of technologies not approved by ANVISA ${ }^{27}$. According to Douw et al. ${ }^{28}$ (2003), HS systems are intended to help streamline the adoption and diffusion processes of new technologies. The potential positive effect of HTA in the preparation of defenses in cases of health judicialization has been pointed out ${ }^{29}$.

The HS has informed the Brazilian judicial system through the arguments shown in the defense pieces of the MH in court and, secondarily, through alert reports and briefs. This is caused because these HS outputs appear among search results for technologies not yet approved by ANVISA on tools such as Google, as they are disseminated through the CONITEC website.

The sharing of metreleptin's internal report with Argentina, case presented in this study, shows that CONITEC's HS outputs can be used by other countries dealing with judicialization as well as other purposes. The generation of scientific evidence was identified as one of the priority strategies for addressing health judicialization in Latin America and the Caribbean ${ }^{30}$, showing the potential use of information provided by HS outputs for the region.

In the study by Packer et al..$^{9}$ (2015) on the structure, processes and outputs of 15 EuroScan members, $80 \%$ of the HS systems studied reported peer review expert involvement. Some of CONITEC's HS outputs are also peer reviewed. As with most HS systems reported in this study, the data in this investigation indicate that there is more than one group of potential users of the information generated by this system.

As the Swedish agency's HS reports, Brazilian outputs do not constitute a complete assessment of new or emerging technology but provide managers with early information about them ${ }^{11}$.

Like other EuroScan members, CONITEC's HS team is small, consisting of three people involved in other activities as well. CONITEC's HS system is part of a department that operates in health technology assessment activities, not constituting thus a separate institution, as well as other members of the international network ${ }^{9}$.

Literature on the results of HS activities is scarce ${ }^{9,32,33}$. The information provided by the HS sections in the recommendation reports has influenced CONITEC's recommendations. This allows us to state that the system described in this study generates repercussions on decision making for the incorporation of technologies into SUS.

From this perspective, the increase in the number of "HS sections in recommendation reports" outputs in 2017 and 2018 shows their relevance to the MH. In 75\% of HS systems, the main purpose of the activities is to support coverage and reimbursement decisions ${ }^{9}$, functions similar to those in the HS sections in the recommendation reports.

An important step of the Brazilian HS system will be to carry out studies focused on specific diseases $^{31}$ and deliver this information to the corresponding thematic areas of the $\mathrm{MH}$, in order to indicate technologies with potential for incorporation into SUS. In the United Kingdom, HS activities provide the National Institute for Health and Care Excellence (NICE) with information on technology incorporation ${ }^{32}$.

Although CONITEC cannot proactively guide the technologies that will be analyzed for incorporation, the internal areas of the $\mathrm{MH}$ may demand these evaluations from the 
commission ${ }^{4}$. Thus, the achievement of the step discussed in the previous paragraph may result in a more proactive profile of activities performed by the CONITEC's HS system. In this sense, the expectation that the HS system could identify early adopting technologies that need to be evaluated for proper use has been partially met ${ }^{13}$.

Translating briefs and alert reports into English and Spanish and making them available in the EuroScan database and the CONITEC website will allow the use of information by institutions conducting HTA and HS activities worldwide. Other challenges for CONITEC's HS system will be to show information on drug obsolescence and shortages ${ }^{12}$, as well as to improve the dissemination strategies of the developed outputs.

The construction of the Brazilian HS system has involved the Ministry of Health, academia and other stakeholders. These activities have resulted in the institutional recognition of the methodology as an important HTA phase to inform health managers about the best evidence of new and emerging technologies with the potential to have legal, ethical, organizational, and patient care implications.

\section{REFERENCES}

1. Murphy K, Packer C, Stevens A, Simpson S. Effective early warning systems for new and emerging health technologies: developing an evaluation framework and an assessment of current systems. Int J Technol Assess Health Care. 2007;23(3):324-30. https://doi.org/10.1017/S0266462307070493

2. Banta D. What is technology assessment? Int J Technol Assess Health Care. 2009;25 Suppl 1:7-9. https://doi.org/10.1017/S0266462309090333

3. Brasil. Lei n. 8.080, de 19 de setembro de 1990. Dispõe sobre as condições para a promoção, proteção e recuperação da saúde, a organização e o funcionamento dos serviços correspondentes e dá outras providências. Brasília, DF: 1990 [citado 3 abr 2018]. Available from: http://www.planalto.gov.br/ccivil_03/leis/l8080.htm

4. Brasil. Lei № 12.401, de 28 de abril de 2011. Altera a Lei no 8.080, de 19 de setembro de 1990, para dispor sobre a assistência terapêutica e a incorporação de tecnologia em saúde no âmbito do Sistema Único de Saúde - SUS. Diario Oficial Uniao. 29 abril 2011; Seção 1:1

5. Yuba TY, Novaes HMD, Soárez PC. Challenges to decision-making processes in the national HTA agency in Brazil: operational procedures, evidence use and recommendations. Health Res Policy Syst. 2018;16(1):40 https://doi.org/10.1186/s12961-018-0319-8

6. Carlsson P, Jørgensen T. Scanning the horizon for emerging health technologies: conclusions from a European Workshop. Int J Technol Assess Health Care. 1998;14(4):695-704. https://doi.org/10.1017/S0266462300012010

7. Simpson S, editor. EuroScan International Network (EuroScan). A toolkit for the identification and assessment of new and emerging health technologies 2. ed. Birmingham (UK): University of Birminghan; 2014 [citado 3 abr 2018]. Available from: https://www.euroscan.org/methods/ methods-toolkit/

8. Migliore A, Perrini MR, Jefferson T, Cerbo M. Implementing a national early awareness and alert system for new and emerging health technologies in Italy: the COTE Project. Int J Technol Assess Health Care. 2012;28(3):321-6. https://doi.org/10.1017/S0266462312000384

9. Packer C, Simpson S, Almeida RT. EuroScan International Network member agencies: their structure, processes, and outputs. Int J Technol Assess Health Care. 2015;31(1-2):78-85. https://doi.org/10.1017/S0266462315000100

10. Tark JY, Jeong JY, Lee M, Park E, Park J, Park JJ, et al. Early assessment and prediction of potential impact of the implantation of polyurethane scaffold in partial meniscal lesions: a pilot horizon scanning activity in South Korea. Int J Technol Assess Health Care. 2015;31(6):380-9. https://doi.org/10.1017/S0266462315000689

11. Eriksson I, Wettermark B, Persson M, Edström M, Godman B, Lindhé A, et al. The Early Awareness and Alert System in Sweden: history and current status. Front Pharmacol. 2017;8:674. https://doi.org/10.3389/fphar.2017.00674 
12. Gutierrez-Ibarluzea I, Simpson S, Benguria-Arrate G; Members of EuroScan International Network. Early Awareness and Alert Systems: an overview of EuroScan methods. Int J Technol Assess Health Care. 2012;28(3):301-7. https://doi.org/10.1017/S0266462312000360

13. Pichon-Riviere A, Silva Elias FT, Rivero VG, Vaca CP. Early awareness and alert activities in Latin America: current situation in four countries. Int J Technol Assess Health Care. 2012;28(3):315-20. https://doi.org/10.1017/S0266462312000311

14. Nascimento A, Vidal AT, Almeida RT. Mapeamento das preferências de atores estratégicos sobre os critérios de priorização para o monitoramento do horizonte tecnológico em saúde. Cad Saude Publica. 2016;32(7):e00177614. https://doi.org/10.1590/0102-311X00177614

15. Toma TS, Pereira TV, Vanni T, Barreto JOM, editores. Avaliação de tecnologias de saúde \& políticas informadas por evidências. São Paulo: Instituto de Saúde; 2017 [citado 3 abr 2018]. (Temas em Saúde Coletiva, 22). Available from: http://www.saude.sp.gov.br/resources/institutode-saude/homepage/pdfs/avaliacao_tecnologia_saudepolticas_inf_evidencias.pdf

16. Ministério da Saúde (BR); Hospital Alemão Oswaldo Cruz. Monitoramento do horizonte tecnológico no Brasil: avanços e desafios. Brasília, DF; 2018 [citado 3 abr 2018]. Available from: http://bvsms.saude.gov.br/bvs/publicacoes/monitoramento_horizonte_tecnologico_ brasil.pdf

17. CONITEC: Comissão Nacional de Incorporação de Tecnologias no SUS Brasília, DF: CONITEC; 2011 [citado 30 set 2018]. Available from: http://conitec.gov.br/

18. Gomes PTC, Souza AB, Vidal AT. Alerta de tecnologias novas e emergentes: o desafio de informar a sociedade. Rev Eletron Gestao Saude. 2015;6 Supl 4:3111-26. DOI: $10.18673 / g s . v 6 i 4.22102$

19. Gomes PTC, Souza AB, Vidal AT, Canuto V, Petramale C. PP109 Horizon Scanning for Information providing In Brazil. Int J Technol Assess Health Care. 2017;33 Suppl 1:123-4. https://doi.org/10.1017/S0266462317002707

20. Gomes KB, Fernandes AP, Ferreira ACS, Pardini H, Garg A, Magré J, et al. Mutations in the Seipin and AGPAT2 genes clustering in consanguineous families with Berardinelli-Seip congenital lipodystrophy from two separate geographical regions of Brazil. Int J Clin Endocrinol Metab. 2004;89(1):357-61. https://doi.org/10.1210/jc.2003-030415

21. U.S Food and Drug Administration. Silver Spring, MD: FDA [citado 2 dez 2018]. Available from: https://www.fda.gov/

22. ISHN: Integrated Solutions Health Networks. Johnson City, TN: ISHN; c2010 [citado 2 dez 2018]. Available from: http://www.ishnonline.com/

23. Ministério da Saúde (BR). Uso da metreleptina para tratamento da Síndrome Berardinelli-Seip. Brasília, DF; 2016. (Nota Técnica nº 243/2016 - DGITS/SCTIE/MS).

24. Souza AB, Vidal A, Canuto V, Petramale C, Gomes P. PP086 Horizon Scanning in multiple sclerosis decisions in Brazil. Int J Technol Assess Health Care. 2017;33 Suppl 1:110-1. https://doi.org/10.1017/S0266462317002549

25. Ministério da Saúde (BR), Comissão Nacional de Incorporação de Tecnologias no SUS. Relatório de recomendação $\mathrm{n}^{\circ}$ 385. Brasíia, DF: CONITEC; 2018.

26. Ministério da Saúde (BR). Portaria № 1.419, de 8 de junho de 2017. Aprova os Regimentos Internos e o Quadro Demonstrativo de Cargos em Comissão e das Funções de Confiança das unidades integrantes da Estrutura Regimental do Ministério da Saúde. Brasília, DF; 2017 [citado 3 abr 2018]. Available from: http://bvsms.saude.gov.br/bvs/saudelegis/gm/2017/ prt1419_09_06_2017.html

27. Oliveira MRM, Delduque MC, Sousa MF, Mendonça AVM. Judicialização da saúde: para onde caminham as produções científicas? Saude Debate. 2015;39(105):525-35. https://doi.org/10.1590/0103-110420151050002019

28. Douw K, Vondeling H, Eskildsen D, Simpson S. Use of the Internet in scanning the horizon for new and emerging health technologies: a survey of agencies involved in horizon scanning. J Med Internet Res. 2003;5(1):e6. https://doi.org/10.2196/jmir.5.1.e6

29. Aleman A, Perez Galan A. Impact of health technology assessment in litigation concerning access to high-cost drugs. Int J Technol Assess Health Care. 2017;33(4):411-4. https://doi.org/10.1017/S0266462317000575

30. Pinzón-Flórez CE, Chapman E, Cubillos L, Reveiz L. Prioritization of strategies to approach the judicialization of health in Latin America and the Caribbean. Rev Saude Publica. 2016;50:56. https://doi.org/10.1590/S1518-8787.2016050005728 
31. Oortwijn W, Sampietro-Colom L, Habens F, Trowman R. How can health systems prepare for new and emerging health technologies? The role of horizon scanning revisited. Int J Technol Assess Health Care. 2018;34(3):254-9. https://doi.org/10.1017/S0266462318000363

32. Packer C, Fung M, Stevens A. Analyzing 10 years of early awareness and alert activity in the United Kingdom. Int J Technol Assess Health Care. 2012;28(3):308-14. https://doi.org/10.1017/S026646231200030X

33. Simpson S, Packer C, Carlsson P, Sanders JM, Ibarluzea IG, Fay A-F, et al. Early identification and assessment of new and emerging health technologies: actions, progress, and the future direction of an international collaboration--EuroScan. Int J Technol Assess Health Care. 2008;24(4):518-25. https://doi.org/10.1017/S0266462308080689

Authors' contributions: PTCG: study conception, planning, analysis, interpretation and writing. VEM: manuscript analysis, interpretation and revision. TCB: study interpretation and writing. DG: study planning, data analysis, writing and review.

Conflict of Interest: The authors declare no conflict of interest. 